\title{
HUBUNGAN ANTARA POLA ASUH OTORITATIF DENGAN KEMANDIRIAN PADA SISWA KELAS XI JURUSAN AKUNTANSI SMKN 12 JAKARTA
}

\author{
Putri Suci Budi Lestari \\ Alumni Fakultas Ekonomi Universitas Negeri Jakarta \\ Santi Susanti \\ Dosen Fakultas Ekonomi Universitas Negeri Jakarta \\ Susi Indriyani \\ Dosen Fakultas Ekonomi Universitas Negeri Jakarta
}

\begin{abstract}
ABSTRAK
Penelitian ini bertujuan untuk mengetahui hubungan antara pola asuh otoritatif yang diterapkan oleh orang tua dengan kemandirian pada siswa kelas XI Jurusan Akuntansi SMKN 12 Jakarta. Metode dalam penelitian ini adalah metode survey dengan pendekatan korelasional. Data penelitian dikumpulkan dengan menggunakan skala motivasi berprestasi dan skala kepercayaan diri. Teknik pengambilan sampel yang digunakan dalam penelitian ini adalah Proporsional Random Sampling. Populasi terjangkau dalam penelitian ini adalah siswa kelas XI Jurusan Akuntansi SMKN 12 Jakarta, berjumlah 71 siswa dan sampel yang digunakan berdasarkan tabel Isacc dan Michael adalah 60 siswa. Berdasarkan hasil penelitian diperoleh persamaan regresi $Y=75,80+$ $0,43 X$ yang menunjukkan bahwa taksiran regresi $Y$ atas $X$ berdistribusi normal yang dibuktikan dengan hasil perhitungan $L_{0}(0,0565)<L_{t}(0,114)$. Selain normal, persamaan regresi ini juga berbentuk linier dan berarti, hal ini dibuktikan dengan $F_{\text {hitung }}(1,28)<F_{\text {tabel }}(1,99)$ dan $F_{\text {hitung }}(14,45)>F_{\text {tabel }}(4,00)$. Dalam perhitungan koefisien korelasi dan keberartian koefisien korelasi diperoleh hasil bahwa terdapat hubungan positif yang signifikan antara pola asuh otoritatif dengan kemandirian pada siswa. Hal ini dibuktikan melalui perhitungan koefisien korelasi dengan menggunakan rumus product moment dari Pearson yang menghasilkan $r_{x y}$ sebesar 0,447 dan perhitungan keberartian koefisien korelasi diperoleh $t_{\text {hitung }}(3,801)>t_{\text {tabel }}(1,67)$. Selain itu perhitungan koefisien determinasi menunjukkan hasil sebesar $20 \%$. Hal ini dapat diartikan
\end{abstract}


bahwa pola asuh otoritatif memberikan pengaruh sebesar $20 \%$ terhadap kemandirian siswa.

Kata kunci: pola asuh otoritatif; kemandirian

\section{PENDAHULUAN}

Di era globalisasi ini kehidupan semakin kompleks dan akan semakin berkembang dari masa ke masa yang berarti kehidupan di masa mendatang akan semakin kompleks. Kompleksitas tersebut mendesak individu untuk meningkatkan kemampuannya sesuai dengan perkembangan zaman. Hal ini menyebabkan individu cenderung menyerap arus globalisasi tanpa menyaringnya terlebih dahulu. Kondisi individu yang seperti ini dikarenakan individu tidak memiliki ketahanan dalam mempertahankan identitasnya.

Remaja merupakan masa peralihan dari masa anak-anak menjadi dewasa. Pada masa remaja ini, individu memiliki tugas perkembangan yang paling utama, yaitu pencarian identitas atau jati diri. Dalam upaya mencari jati diri, remaja membutuhkan kemandirian sehingga remaja tidak bergantung pada orang lain dan dapat bertanggung jawab atas perilakunya. Kemandirian merupakan kemampuan seseorang untuk melakukan segala sesuatu sendiri dan tidak bergantung pada orang lain sehingga dapat mempertanggungjawabkan perilaku yang dilakukannya sendiri.

Kemandirian remaja dipengaruhi oleh beberapa hal, namun hal yang paling mempengaruhi kemandirian remaja berasal dari pola asuh yang diterapkan orang tua. Orang tua yang menerapkan pola asuh otoritatif dalam mendidik anakanaknya akan menghasilkan anakanak yang mandiri.

\section{KAJIAN PUSTAKA \\ Kemandirian}

Kemandirian merupakan salah satu aspek pentimg dalam kehidupan manusia. Menurut Kamus Besar Bahasa Indonesia, kemandirian merupakan "keadaan dapat berdiri sendiri tanpa bergantung pada orang lain". Sutari Imam Barnadib (dalam Enung Fatimah, 2006) berpendapat bahwa kemandirian meliputi "perilaku mampu berinisiatif, mampu mengatasi hambatan atau masalah, mempunyai rasa percaya diri, dan 
dapat melakukan sesuatu sendiri tanpa bantuan orang lain." Sejalan dengan Barnadib, Agoes Dariyo (2004) berpendapat bahwa orang yang mandiri akan berusaha menyelesaikan masalah dalam hidupnya sendiri dan menggunakan segenap kemampuan, inisiatif, daya kreasi, serta kecerdasannya dengan sebaik-baiknya. Dengan adanya kemandirian dalam diri seseorang, orang tersebut dapat mengaktualisasi diri dengan membuktikan kreativitasnya.

Selanjutnya, Hermann Holstein yang berpendapat bahwa kemandirian merupakan penampilan seseorang yang bertingkah laku secara aktif dengan kesadarannya sendiri, aktif dalam memberikan pendapat, melakukan penilaian, dan mengambil keputusan yang dapat dipertanggungjawabkan. Individu yang mandiri menurut $\mathrm{M}$. Ali dan $\mathrm{M}$. Asrori (2004) adalah individu yang berani mengambil keputusan dilandasi oleh pemahaman atas segala konsekuensi dari tindakannya. Kemudian Muttadin menambahkan bahwa kemandirian merupakan suatu keadaan dimana seseorang memiliki hasrat bersaing untuk maju demi kebaikan dirinya, mampu mengambil keputusan dan inisiatif untuk mengatasi masalah yang dihadapi, memiliki kepercayaan diri dalam mengerjakan tugas-tugasnya, dan bertanggungjawab terhadap apa yang dilakukannya.

Berdasarkan pendapat para ahli yang telah dikemukakan di atas, dapat ditarik kesimpulan bahwa individu yang mandiri adalah individu yang mampu menyelesaikan masalahnya sendiri, tidak bergantung pada orang lain, memiliki inisiatif, dan dapat mengambil keputusannya sendiri secara bertanggung jawab.

\section{Pola Asuh Otoritatif}

Pola asuh otoritatif merupakan pola asuh dimana orang tua memberikan kebebasan kepada anak untuk melakukan hal yang dianggap baik namun tetap memberikan batasan dan tanggung jawab akan hal-hal yang dilakukannya. Agoes Dariyo (2004) berpendapat bahwa kedudukan antara orang tua dan anak pada pola asuh ini sejajar. Suatu keputusan diambil bersama dengan mempertimbangkan kedua belah pihak. Anak diberi kebebasan yang bertanggungjawab, artinya apa yang dilakukan oleh anak tetap harus dibawah pengawasan orang tua dan dapat dipertanggungjawabkan secara moral. Dengan menerapkan pola asuh ini, anak akan menjadi seorang individu yang mempercayai orang lain, bertanggung jawab 
terhadap tindakannya, tidak munafik, dan jujur.

Sejalan dengan Agoes Dariyo, Santrock (2003) berpendapat bahwa gaya pengasuhan otoritatif akan mendorong remaja untuk bebas tetapi tetap memberikan batasan dan mengendalikan tindakan-tindakan mereka. Komunikasi verbal timbal balik dapat berlangsung bebas. Selain itu, orang tua dengan gaya pengasuhan ini juga akan bersikap hangat dan dapat membesarkan hati remaja. Pengasuhan otoritatif berkaitan dengan perilaku sosial remaja yang kompeten sehingga menghasilkan remaja yang memiliki kesadaran tinggi dan bertanggung jawab.

Selanjutnya Sri Lestari (2012) menyatakan dengan lengkap bahwa orang tua yang menerapkan pola asuh otoritatif, mengarahkan perilaku anak secara rasional, dengan memberikan penjelasan terhadap maksud dari aturan-aturan yang diberlakukan. Orang tua mendorong anak untuk mematuhi aturan dengan kesadaran sendiri. Orang tua menghargai kehadiran dan kualitas kepribadian anak sebagai keunikan pribadi. Anak dengan orang tua yang otoritatif akan cenderung periang, memiliki rasa tanggung jawab sosial, percaya diri, berorientasi prestasi, dan lebih kooperatif.

Menurut Mussen dkk (1992) orang tua dengan pola asuh otoritatif lebih bersikap hangat, mengasihi, mendukung, penuh kesadaran, dan memiliki komunikasi yang baik dengan anak-anak mereka. Walaupun mereka menghargai kemandirian dan keputusan anak, mereka tetap memegang teguh kekuasaan mereka. Orang tua yang otoritatif menggunakan disiplin induktif yang menerima pendapat anak dan membolehkan mereka mengambil bagian dalam penentuan sebuah keputusan, mempertanyakan kaidah, dan mempengaruhi jalannya interaksi dalam keluarga. Orang tua otoritatif ini juga menyajikan standar yang jelas kepada anak-anak mereka.

Berdasarkan

pendapat beberapa ahli di atas dapat disimpulkan bahwa pola asuh otoritatif adalah pola asuh dimana orang tua memberikan kebebasan yang bertanggung jawab pada anak, berpikir rasional, menghargai kepribadian anak, dan mengikutsertakan anak dalam menentukan keputusan. Keluarga yang menerapkan pola asuh otoritatif juga cenderung memiliki komunikasi yang hangat antara anak dan orang tua. 


\section{Penelitian yang Relevan}

Penelitian sebelumnya yang relevan dengan penelitian ini adalah penelitian yang dilakukan oleh Anastasia Arika Widiana dan Heni Nugraheni, mahasiswi Fakultas Psikologi Universitas Setia Budi Surakarta, dengan judul "Hubungan antara Pola Asuh Demokratis dengan Kemandirian pada Remaja". Pada variabel kemandirian, teori ahli yang digunakan adalah teori dari Hurlock dan Mussen sedangkan variabel pola asuh menggunakan teori Baumrind dan Barnadib. Hasil penelitian pada penelitian ini adalah pola asuh demokratis mempengaruhi kemandirian remaja sebesar $15,6 \%$.

Penelitian relevan lainnya adalah penelitian yang dilakukan oleh Arief Purnomo Julianto, karyawan Dinas Kesehatan Kabupaten Pekalongan, yang berjudul "Hubungan Pola Asuh Orang Tua dengan Tingkat Kemandirian Anak Usia Sekolah Di SDN Panjang Wetan 01 Pekalongan". Pada variabel kemandirian, teori ahli yang digunakan adalah teori Hurlock sedangkan variabel pola asuh menggunakan teori Baumrind. Hasil penelitian dalam penelitian ini adalah pola asuh mempengaruhi kemandirian siswa.
Penelitian relevan selanjutnya dilakukan oleh Danang Danu Suseno dan Irdawati,S.Kep.,Ns.,M.Si.Med dengan judul "Hubungan antara Pola Asuh Orang Tua dengan Kemandirian Anak Usia PraSekolah di TK Aisyiyah Mendungan Sukoharjo". Pada variabel kemandirian, teori ahli yang digunakan adalah teori dari Erikson sedangkan variabel pola asuh menggunakan teori Baumrind . Hasil penelitian ini menunjukkan bahwa pola asuh mempengaruhi kemandirian siswa.

\section{Kerangka Teoritik}

Pola asuh otoritatif merupakan pola asuh yang paling tepat diterapkan oleh orang tua demi meningkatkan kemandirian remaja. Hal ini diperkuat oleh pernyataan Mussen, dkk (1992) yang mengatakan bahwa "anak-anak dari orang tua otoritatif cenderung lebih menurut, senang bergaul serta mandiri sejak awal."

Selanjutnya Elizabeth Hurlock (1978) berpendapat bahwa orang tua dengan pola asuh otoritatif dapat "menumbuhkan penyesuaian pribadi dan sosial yang baik serta menghasilkan kemandirian dalam berpikir, inisiatif dalam tindakan, dan konsep diri yang sehat, positif serta penuh rasa percaya diri yang 
direfleksikan dalam perilaku yang aktif terbuka dan sopan."

Hal ini diperkuat oleh pernyataan Lawrence E. Shapiro (2003) yang menyatakan bahwa orang tua otoritatif lebih memungkinkan untuk menghasilkan anak-anak yang percaya diri, mandiri, imajinatif, mudah beradaptasi, dan disukai banyak serta menghasilkan anak-anak dengan kecerdasan emosional berderajat tinggi.

Sejalan dengan pendapat beberapa ahli di atas, Gordon (1991) berpendapat bahwa orang tua yang menggunakan metode otoritatif akan menghasilkan anakanak yang nilai-nilai sekolahnya bertambah baik, hubungan dengan teman sebaya lebih baik, lebih terbuka dalam menyatakan perasaan, jarang marah-marah, berkurangnya sikap bermusuhan terhadap sekolah, lebih bertanggung jawab atas pekerjaanpekerjaan dalam rumah, lebih berdikari (berdiri diatas kaki sendiri), lebih percaya diri, lebih bergembira, dan perbaikan lainnya.

\section{Perumusan Hipotesis}

Hipotesis penelitian ini sebagai berikut : "terdapat hubungan antara pola asuh otoritatif dengan kemandirian".

\section{METODOLOGI PENELITIAN}

Tujuan penelitian ini adalah untuk mengetahui hubungan antara pola asuh otoritatif dengan kemandirian pada siswa kelas XI Jurusan Akuntansi SMKN 12 Jakarta.

Penelitian ini dilakukan di SMKN 12 Jakarta yang beralamat di Jalan Kebon Bawang XV, Tanjung Priok, Jakarta Utara.

Metode yang digunakan dalam penelitian ini adalah metode survei dengan pendekatan korelasional, untuk mengetahui hubungan suatu variabel dengan variabel lain yang sedang diteliti.

Populasi dalam penelitian ini adalah siswa kelas XI SMKN 12 Jakarta tahun ajaran 2012/2013 yang berjumlah 218 siswa dan terdiri dari 3 jurusan, yaitu Jurusan Akuntansi, Jurusan Pemasaran, serta Jurusan Administrasi Perkantoran. Populasi terjangkau dalam penelitian ini adalah siswa kelas XI Jurusan Akuntansi tahun ajaran 2012/2013 yang berjumlah 71 siswa.

Teknik pengambilan sampel yang digunakan dalam penelitian ini adalah Proportional Random Sampling. Berdasarkan tabel Isaac dan Michael penentuan jumlah sampel dari populasi tertentu pada tingkat kesalahan (sampling error) 
$5 \%$ maka diambil sampel berjumlah 60 siswa kelas XI Jurusan Akuntansi SMKN 12 Jakarta.

Pola asuh otoritatif dan kemandirian siswa diukur dengan menggunakan skala likert dengan pernyataan yang disesuaikan dengan indikator dari masingmasing variabel. Adapun indikator untuk pola asuh otoritiatif adalah keputusan diambil bersama, orang tua memberikan anak kebebasan yang bertanggung jawab, orang tua dan anak memiliki komunikasi yang hangat, orang tua menghargai anak dan mengarahkan perilaku anak secara rasional. Sedangkan indikator untuk kemandirian adalah tidak bergantung pada orang lain, menyelesaikan masalah sendiri, menggunakan inisiatif, dan dapat mengambil keputusan sendiri.

Analisis data dilakukan berdasarkan urutan, yaitu persamaan regresi, uji persyaratan analisis yang terdiri atas uji normalitas, uji linieritas, dan uji hipotesis terdiri atas uji keberartian regresi, uji koefisien korelasi, uji keberartian koefisien korelasi, dan uji koefisien determinasi.

Persamaan regresi untuk mengetahui besar pengaruh variabel satu dengan variabel yang lain dengan rumus sebagai berikut:

$$
\hat{\mathrm{Y}}=a+b X
$$

$$
\begin{aligned}
a & =\frac{\left(\sum Y\right)\left(\sum X^{2}\right)-\left(\sum X\right)\left(\sum X Y\right)}{n\left(\Sigma X^{2}\right)-\left(\sum X\right)^{2}} \\
b & =\frac{n\left(\sum X Y\right)-(\Sigma X)\left(\sum Y\right)}{n\left(\sum X^{z}\right)-(\Sigma X)^{2}}
\end{aligned}
$$

Selanjutnya uji persyaratan analisis yang pertama yaitu uji normalitas galat taksiran regresi $Y$ dan $X$ dengan uji Liliefors, pada taraf signifikan $(\alpha)=0,05$, dengan rumus :

\section{$\mathbf{L o}=\mathbf{F}(\mathrm{Zi})-\mathbf{S}(\mathrm{Zi})$}

Syarat normalitas adalah Ho jatuh di daerah penerimaan, berarti $L_{\text {hitung }}<$ $L_{\text {tabel. }}$.

Pengujian yang kedua adalah uji linieritas regresi yang bertujuan untuk mengetahui apakah persamaan regresi yang diperoleh merupakan bentuk linear atau tidak. Perhitungan $F_{\text {hitung }}$ pada uji lineritas sebagai berikut:

$$
F_{\text {hitung }}=\frac{S^{2}}{S^{2}} \underline{T}
$$

Kemudian uji hipotesis yang pertama yaitu uji keberatian regresi. Digunakan untuk mengetahui apakah persamaan regresi yang diperoleh berarti atau tidak. Perhitungan $F_{\text {hitung pada uji }}$ keberartian regresi sebagai berikut: $F_{\text {hitung }}=\frac{\mathbf{S}^{2} \text { reg }}{\mathbf{S}^{2}{ }_{\text {res }}}$

Selanjutnya analisis koefisien korelasi digunakan untuk mengetahui ada tidaknya hubungan antara variabel bebas dengan variabel terikat. Untuk mencari 
koefisien korelasi, digunakan rumus product moment dari Pearson sebagai berikut :

$r_{x y}=\frac{n(\Sigma x y)-(\Sigma x)(\Sigma y)}{\sqrt{\left[n \cdot \Sigma x^{2}-(\Sigma x)^{2}\right]\left[n \cdot \Sigma y^{2}-(\Sigma y)^{2}\right]}}$

Pengujian selanjutnya, untuk mengetahui keberartian hubungan antara pola asuh otoritatif dengan kemandirian digunakan rumus uji $\mathrm{t}$ yaitu:

$t=\frac{r \sqrt{n-2}}{\sqrt{1-r^{2}}}$

Pengujian yang terakhir adalah uji koefisien determinasi. Uji koefisien determinasi berguna untuk mengetahui seberapa besar variabel terikat (kemandirian) dipengaruhi oleh varibel bebas (pola asuh otoritatif). Uji koefisien determinasi ini dihitung dengan rumus sebagai berikut:

$$
K D=r_{x y}{ }^{2} \times 100 \%
$$

\section{HASIL PENELITIAN}

Data kemandirian siswa diperoleh dari angket kemandirian siswa dengan 42 butir pernyataan dan jumlah responden sebanyak 60 siswa. Seluruh butir-butir pernyataan dalam variabel terikat ini sudah melalui proses validitas dan reliabilitas.

Berdasarkan data yang terkumpul, diperoleh skor terendah adalah 121 dan skor tertinggi adalah 185, jumlah skor $Y$ adalah 9.225, sehingga rata-rata skor kemandirian $(Y)$ sebesar 153,75, varians $\left(\mathrm{S}^{2}\right)$ sebesar 196,67 dan simpangan baku atau standar deviasi (S) sebesar 14,024.

Distribusi data kemandirian siswa menyebar antara 121-185, dimana rentang skor adalah 64, banyak kelas interval adalah 7 dan panjang interval adalah 10. Berikut ini adalah distribusi frekuensi yang terdapat dalam tabel berikut ini:

\begin{tabular}{|l|c|}
\hline $\begin{array}{l}\text { Kelas } \\
\text { Interval }\end{array}$ & $\begin{array}{c}\text { Frekuensi } \\
\text { Absolut }\end{array}$ \\
\hline $121-130$ & 3 \\
\hline $131-140$ & 10 \\
\hline $141-150$ & 8 \\
\hline $151-160$ & 16 \\
\hline $161-170$ & 18 \\
\hline $171-180$ & 4 \\
\hline $181-190$ & 1 \\
\hline & 60 \\
\hline
\end{tabular}

Berdasarkan tabel di atas dapat dilihat bahwa frekuensi kelas tertinggi variabel kemandirian terletak pada interval ke 5, yakni antara 161-170. Terdapat 18 responden dengan frekuensi relatif $30 \%$ dari seluruh responden dalam penelitian yang berada pada kelas interval ini. Indikator dominan pada interval ini adalah siswa dapat mengambil keputusan sendiri. Selanjutnya frekuensi terbesar 
kedua terletak pada interval ke 4 , yakni antara 151-160. Terdapat 16 responden dengan frekuensi relatif sebesar $27 \%$ dari seluruh responden dalam penelitian yang berada pada kelas interval ini. Indikator dominan pada interval ini adalah siswa dapat mengambil keputusan sendiri. Sementara frekuensi terendah variabel ini terletak pada interval ke 7 , yakni antara 181-190. Terdapat 1 responden dengan frekuensi relatif $2 \%$ dari seluruh responden dalam penelitian yang berada pada kelas interval tersebut. Indikator dominan pada interval ini adalah siswa dapat mengambil keputusan sendiri dan dapat menggunakan inisiatif dengan baik. Secara keseluruhan,indikator dominan pada variabel kemandirian ini adalah dapat mengambil keputusan sendiri.

Siswa kelas XI jurusan Akuntansi SMKN 12 Jakarta memiliki tingkat kemandirian yang tinggi. Hal ini disebabkan oleh $52 \%$ siswa berada pada kategori kemandirian yang tinggi.

Data pola asuh otoritatif diperoleh dari angket kemandirian siswa dengan 46 butir pernyataan dan jumlah responden sebanyak 60 siswa kelas XI Jurusan Akuntansi SMKN 12 Jakarta. Seluruh butirbutir pernyataan dalam variabel terikat ini sudah melalui proses validitas dan reliabilitas.

Berdasarkan data yang terkumpul, diperoleh skor terendah adalah 128 dan skor tertinggi adalah 212, jumlah skor $X$ adalah 10.834 , sehingga rata-rata skor pola asuh otoritatif $(X)$ sebesar 180,57 , varians (S2) sebesar 210,45 dan simpangan baku atau standar deviasi (S) sebesar 14,507.

Distribusi data pola asuh otoritaitf menyebar antara 128-212, dimana rentang skor adalah 84, banyak kelas interval adalah 7 dan panjang interval adalah 12. Berikut ini adalah distribusi frekuensi variabel Pola Asuh Otoritatif:

\begin{tabular}{|c|c|}
\hline Kelas Interval & $\begin{array}{c}\text { Frekuensi } \\
\text { Absolut }\end{array}$ \\
\hline $128-140$ & 1 \\
\hline $141-153$ & 1 \\
\hline $154-166$ & 4 \\
\hline $167-179$ & 24 \\
\hline $180-192$ & 17 \\
\hline $193-205$ & 11 \\
\hline $206-218$ & 2 \\
\hline & 60 \\
\hline
\end{tabular}

Berdasarkan tabel di atas, dapat dilihat bahwa frekuensi kelas tertinggi pertama variabel pola asuh otoritatif terletak pada interval ke 4, yakni antara 167-179. Terdapat 24 responden dengan frekuensi relatif 
$40 \%$ dari seluruh responden dalam penelitian yang berada pada kelas interval ini. Indikator dominan pada interval ini adalah orang tua memberikan kebebasan yang bertanggung jawab pada anak. Selanjutnya frekuensi terbesar kedua terletak pada interval ke 5, yakni antara 180-192. Terdapat 17 responden dengan frekuensi relatif sebesar $28 \%$ dari seluruh responden dalam penelitian yang berada pada kelas interval ini. Indikator dominan pada interval ini adalah orang tua memberikan kebebasan yang bertanggung jawab pada anak. Kemudian frekuensi terbesar ketiga terletak pada interval ke 6, yakni antara 193-205. Terdapat 11 responden dengan frekuensi relatif sebesar $18 \%$ dari seluruh responden dalam penelitian ini. Indikator dominan pada interval ini adalah orang tua memberikan kebebasan yang bertanggung jawab pada anak. Sementara frekuensi terendah variabel ini terletak pada interval ke 1 dan 2, yakni antara 128-140 dan 141-153. Terdapat 1 responden dengan frekuensi relatif $2 \%$ dari seluruh responden dalam penelitian yang berada pada kedua kelas interval tersebut. Indikator dominan pada interval ke-1 adalah orang tua memberikan kebebasan yang bertanggung jawab pada anak. Indikator dominan pada interval ke-2 adalah orang tua dan anak memiliki komunikasi yang hangat. Secara keseluruhan,indikator dominan pada variabel pola asuh otoritatif ini adalah orang tua memberikan kebebasan yang bertanggung jawab pada anak.

Siswa kelas XI jurusan Akuntansi SMKN 12 Jakarta diasuh dengan pola asuh otoritatif yang tinggi. Hal ini disebabkan oleh $83 \%$ siswa berada pada kategori pola asuh otoritatif yang tinggi.

\section{Analisis Data}

Dari perhitungan yang telah dilakukan dalam penelitian ini, diperoleh persamaan regresi $\hat{Y}=$ $75,80+0,43 X$ yang berarti setiap kenaikan satu skor pola asuh otoritatif $(X)$ akan mengakibatkan kenaikan kemandirian $(Y)$ sebesar 0,43 skor pada konstanta 75,80 .

Berdasarkan uji normalitas yang telah dilakukan, diperoleh hasil perhitungan $L_{0}=0,0565$ sedangkan $L_{t}=0,114$. Hal ini berarti $L_{0}(0,0565)$ $<L_{t}(0,114)$ yang membuktikan bahwa populasi siswa kelas XI SMKN 12 Jakarta Tahun Ajaran 2012/2013 berdistribusi normal.

Perhitungan uji linieritas regresi menunjukkan bahwa $F_{\text {hitung }}(1,28)<$ $F_{\text {tabel }}(1,99)$ yang berarti persamaan regresi pada penelitian ini berbentuk regresi linier. 
Dalam pengujian keberartian regresi dapat disimpulkan bahwa $F_{\text {hitung }}>F_{\text {tabel, }}$ yaitu $14,45>4,00$, ini berarti $H_{0}$ ditolak dan sampel dinyatakan memiliki regresi yang berarti.

Dengan menggunakan rumus product moment dari Pearson, diperoleh hasil perhitungan koefisien korelasi sederhana antara pola asuh otoritatif dengan kemandirian sebesar thitung $(3,801)$ $>t_{\text {tabel }}(1,67)$ dan diperoleh $r_{x y}=$ 0,447 . Hal ini dapat disimpulkan bahwa terdapat hubungan yang positif dan signifikan antara pola asuh otoritatif dengan kemandirian siswa.

Pengujian yang terakhir adalah uji koefisien determinasi, pada pengujian ini diperoleh hasil $20 \%$. Hal ini berarti $20 \%$ kemandirian siswa ditentukan oleh pola asuh otoritatif, sedangkan sisanya dipengaruhi beberapa hal lainnya, seperti kecerdasan emosi, kepercayaan diri, urutan kelahiran, dan interaksi sosial dengan teman sebaya.

\section{Pembahasan}

Berdasarkan hasil pengujian hipotesis yang telah dijelaskan di atas, diperoleh data yang menunjukkan bahwa terdapat hubungan yang positif dan signifikan antara pola asuh otoritatif yang diterapkan orang tua siswa dengan kemandirian siswa kelas XI Jurusan Akuntansi SMKN 12 Jakarta. Hal ini diperkuat oleh para ahli seperti Mussen, Elizabeth Hurlock, Lawrence Shapiro, dan Thomas Gordon.

Hubungan yang positif antara pola asuh otoritatif dengan kemandirian siswa ini dapat diartikan bahwa semakin tinggi pola asuh otoritatif orang tua siswa yang ditandai dengan indikator memberikan anak kebebasan anak yang bertanggung jawab, maka akan semakin tinggi pula kemandirian siswa yang ditandai dengan indikator kemampuan siswa dalam mengambil keputusan sendiri. Demikian pula sebaliknya, semakin sedikit orang tua memberikan kebebasan bertanggung jawab kepada anak, maka akan semakin rendah pula kemandirian siswa yang ditandai dengan rendahnya kemampuan siswa dalam mengambil keputusan sendiri.

Besarnya variasi variabel kemandirian siswa ditentukan oleh variabel pola asuh otoritatif dan dapat diketahui dengan cara mengkuadratkan nilai koefisien korelasi sederhana sehingga menghasilkan nilai koefisien determinasi sebesar $20 \%$ secara statistik nilai ini memberikan 
pengertian bahwa $20 \%$ variasi perubahan kemandirian siswa kelas XI Jurusan Akuntansi SMKN 12 Jakarta dipengaruhi oleh pola asuh otoritatif yang diterapkan oleh orang tua siswa.

Pola asuh otoritatif atau pola asuh dimana orang tua membimbing anak-anak remaja tanpa memerintah mereka merupakan pola asuh yang paling tepat diterapkan oleh orang tua demi meningkatkan kemandirian remaja. Hal ini dikarenakan orang tua dengan pola asuh tersebut akan memberikan kebebasan kepada remaja dengan tetap memberikan batasan dan mengendalikan tingkah laku remaja. Selain itu, orang tua dengan pola asuh otoritatif akan memberikan kesempatan kepada anak-anak untuk membuat keputusan sendiri.

Berdasarkan penelitian yang peneliti lakukan dan diperkuat oleh penelitian yang relevan serta pendapat para ahli, dapat disimpulkan bahwa siswa yang diasuh oleh orang tua yang menerapkan pola asuh otoritatif akan memiliki kemandirian yang tinggi sehingga siswa dapat mengambil keputusan sendiri, tidak memiliki ketergantungan terhadap orang lain, dan dapat mempertahankan jati dirinya. Sebaliknya, jika siswa tidak diasuh dengan pola asuh otoritatif kecil kemungkinan bagi siswa untuk memiliki kemandirian yang tinggi. Dengan kemandirian yang rendah, siswa berarti akan sangat bergantung kepada orang lain dan tidak dapat mengambil keputusan sendiri sehingga siswa tidak dapat mempertahankan jati dirinya sendiri.

Peneliti menyadari bahwa dalam penelitian ini masih banyak kekurangan dan keterbatasan yang peneliti alami selama melakukan penelitian ini, diantaranya yaitu keterbatasan faktor yang diteliti yakni peneliti hanya meneliti mengenai hubungan antara pola asuh otoritatif dengan kemandirian pada siswa. Sedangkan kemandirian siswa juga dapat dipengaruhi oleh hal-hal lainnya seperti kecerdasan emosi, kepercayaan diri, urutan kelahiran, dan interaksi sosial dengan teman sebaya. Selain itu, dalam penelitian ini peneliti hanya menggunakan kuesioner dalam pengumpulan data, sehingga dikhawatirkan hal tersebut akan menghasilkan hasil yang bias dari responden sehingga tidak mencerminkan kondisi yang sebenarnya.

\section{KESIMPULAN}

Berdasarkan pengolahan data, pengetahuan deskripsi, analisis dan interpretasi data yang telah 
dilakukan dan diuraikan pada babbab sebelumnya, maka disimpulkan terdapat hubungan yang sangat erat antara pola asuh otoritatif dengan kemandirian siswa. Hal ini dapat diartikan semakin tinggi pola asuh otoritatif orang tua siswa yang ditandai dengan indikator memberikan anak kebebasan anak yang bertanggung jawab, maka akan semakin tinggi pula kemandirian siswa yang ditandai dengan indikator kemampuan siswa dalam mengambil keputusan sendiri. Hasil penelitian ini diperkuat dengan hasil penelitian relevan dan pendapat para ahli, seperti telah dijelaskan sebelumnya, yang menyatakan bahwa pola asuh otoritatif dapat meningkatkan kemandirian siswa.

Pada penelitian ini diperoleh nilai koefisien korelasi rxy sebesar 0,447. Nilai ini memberikan pengertian bahwa pola asuh otoritatif sangat berkaitan erat dengan kemandirian siswa. Hal ini ditandai dengan semakin tinggi pola asuh otoritatif yang diterapkan oleh orang tua maka akan semakin tinggi pula kemandirian anak. Tingkat kemandirian siswa dipengaruhi oleh pola asuh otoritatif yang diterapkan oleh orang tua sebesar $20 \%$, sedangkan sisanya dipengaruhi oleh faktor-faktor penyebab kemandirian siswa selain pola asuh otoritatif yang diterapkan orang tua, seperti kecerdasan emosi, kepercayaan diri, urutan kelahiran, dan interaksi sosial dengan teman sebaya.

Pada variabel pola asuh otoritatif, indikator yang paling dominan dalam membentuk kemandirian siswa adalah orang tua memberikan kebebasan yang bertanggung jawab kepada anak. Sedangkan indikator pola asuh otoritatif yang kurang dapat dikembangkan adalah keputusan diambil bersama.

\section{Implikasi}

Penelitian ini memiliki implikasi bahwa untuk meningkatkan kemandirian anak, dalam hal ini siswa kelas XI jurusan Akuntansi SMKN 12 Jakarta, orang tua siswa memiliki peran penting, yaitu dengan menerapkan pola asuh otoritatif sebagai pola asuh yang tepat dalam meningkatkan kemandirian siswa. Melalui pemberian kebebasan bertanggung jawab kepada anak oleh orang tua dengan pola asuh otoritatif, anak akan merasa memiliki kebebasan namun tetap memiliki batasan atas kebebasan yang dimiliki. Hal ini akan mengakibatkan anak memiliki kemandirian yang tinggi, karena mereka dapat mengambil keputusan 
dalam hidupnya sendiri dan tidak mudah terpengaruhi oleh orang lain.

Kemandirian yang tinggi pada siswa akan membuat siswa dapat mengambil keputusan sendiri dan tidak memiliki ketergantungan terhadap orang lain. Sebaliknya, jika siswa tidak diasuh dengan pola asuh otoritatif kecil kemungkinan bagi siswa untuk memiliki kemandirian. Dengan kemandirian yang kurang, siswa berarti akan sangat bergantung kepada orang lain dan mudah dipengaruhi oleh orang lain sehingga siswa tidak dapat mempertahankan jati dirinya.

Meskipun hasil penelitian ini menunjukkan bahwa terdapat hubungan positif yang signifikan antara pola asuh otoritatif dengan kemandirian siswa, akan tetapi penelitian ini masih memiliki beberapa keterbatasan. Berdasarkan keterbatasan penelitian tersebut, diharapkan penelitian selanjutnya dapat menambah variabel atau mencari variabel lain karena kemandirian yang merupakan variabel terikat dipengaruhi oleh beberapa hal selain pola asuh orang tua, seperti kecerdasan emosi, kepercayaan diri, urutan kelahiran, dan interaksi sosial dengan teman sebaya. Selain itu, sebaiknya peneliti selanjutnya menentukan populasi yang lebih luas sehingga diperoleh karakteristik yang berbeda dan kesimpulan yang diperoleh dapat diperlakukan secara umum serta memperkaya hasil penelitian yang relevan.

\section{Saran}

Berdasarkan kesimpulan dan implikasi yang telah dijelaskan di atas, berikut adalah saran yang diharapkan dapat menjadi masukan yang bermanfaat bagi semua pihak, saran-saran tersebut adalah:

1. Bagi orang tua, sebaiknya orang tua menerapkan pola asuh otoritatif dalam mengasuh anak, yaitu dengan memberikan kebebasan yang tetap dapat dipertanggungjawabkan, menjalin komunikasi yang baik dengan anak, menghargai perasaan anak, mengarahkan perilaku anak secara rasional, dan mengambil keputusan secara bersama-sama dengan anak. Dengan menerapkan hal tersebut, diharapkan anak akan memiliki kemandirian, sehingga anak dapat menjalani kehidupannya tanpa bergantung dengan orang lain.

2. Bagi sekolah, sebaiknya pihak sekolah dapat membantu meningkatkan kemandirian siswa dengan lebih mengaktifkan siswa dalam kegiatan belajar mengajar dan mengadakan kegiatan yang dapat meningkatkan kemandirian 
siswa seperti pelatihan kepemimpinan, outbond, dan lainlain.

3. Bagi peneliti selanjutnya, peneliti sebaiknya melakukan studi berkelanjutan dari penelitian ini dengan pemilihan jumlah sampel yang lebih luas, tempat penelitian yang berbeda, ataupun menambah subjek penelitian atau variabel lain yang belum diungkap dalam penelitian ini sehingga didapatkan karakteristik siswa yang berbeda dari penelitian ini dan kesimpulan yang diperoleh dapat diperlakukan secara umum. Selain itu, peneliti selanjutnya diharapkan dapat menyebar kuesioner pada orang tua siswa sehingga kemungkinan akan mendapatkan hasil penelitian yang berbeda dengan hasil penelitian ini.

\section{DAFTAR PUSTAKA}

Ali, Mohammad \& M. Asrori. Psikologi Remaja Perkembangan Peserta Didik. Jakarta: Bumi Aksara, 2004.

Arikunto, Suharsimi. Manajemen Penelitian, Jakarta: Rineka Cipta, 2007.

Dariyo, Agoes. Psikologi Perkembangan Remaja. Bogor: Ghalia Indonesia, 2004.
Djaali dan Pudji Muljono. Pengukuran dalam Bidang Pendidikan. Jakarta: PT Grasindo, 2008.

Fatimah, Enung. Psikologi Perkembangan; Perkembangan Peserta Didik. Bandung: Pustaka Setia, 2006.

Holstein, Hermann. Murid Belajar Mandiri; Situasi Belajar Mandiri dalam Pelajaran Sekolah.

Hurlock, Elizabeth B. Perkembangan Anak Jilid 2, Edisi ke-6, Alih Bahasa: Med Meitasari Tjandrasa. Jakarta. Erlangga, 1978.

Kamus Besar Bahasa Indonesia. http://kbbi.web.id/ (diakses pada 28 Maret 2013)

Lestari, Sri. Psikologi Keluarga; Penanaman Nilai dan Penanganan Konflik dalam Keluarga. Jakarta: KENCANA, 2012.

Mussen, dkk. Perkembangan dan Kepribadian Anak, Alih Bahasa: FX. Budianto, dkk. Jakarta: ARCAN, 1992.

Santrock, John W. Adolescence; Perkembangan Remaja Edisi 6 Alih Bahasa: Shinto B. Adelar \& Sherly Saragih. akarta: Erlangga, 2003.

Shapiro, Lawrence E. Mengajarkan Emotional Intelligence pada Anak, Alih Bahasa: Alex Tri Kantjono. Jakarta: PT. 
Gramedia Pustaka Utama, Sugiyono. Statistika untuk $2003 . \quad$ Penelitian. Bandung: CV.

Sudjana. Metode Stastistika, Edisi Alfabeta, 2012.

Enam. Bandung: Tarsito, 2005. 